Management, Procurement and Law Volume 167 Issue MP4

Ten years of PPP in Germany: experiences and perspectives

Jacob, Kochendörfer, von Drygalski and Hilbig

ice | proceedings
Proceedings of the Institution of Civil Engineers

Management, Procurement and Law 167 August 2014 Issue MP4

Pages 180-188 http://dx.doi.org/10.1680/mpal.13.00052

Paper 1300052

Received 11/05/2014_Accepted 05/06/2014

Keywords: private finance initiatives/procurement/public-private

partnerships

\title{
Ten years of PPP in Germany: experiences and perspectives
}

1 Dieter Jacob Prof. Dr.-Ing.

Technische Universität Bergakademie Freiberg, Freiberg, Germany

2 Bernd Kochendörfer Prof. Dr.-Ing.

Technische Universität Berlin, Germany
3 Marcus von Drygalski Dr.-Ing.

Branch Manager, wpm Projektmanagement GmbH, Munich, Germany

4 Corinna Hilbig Dipl.-Kffr.

PSPC GmbH, Berlin, Germany
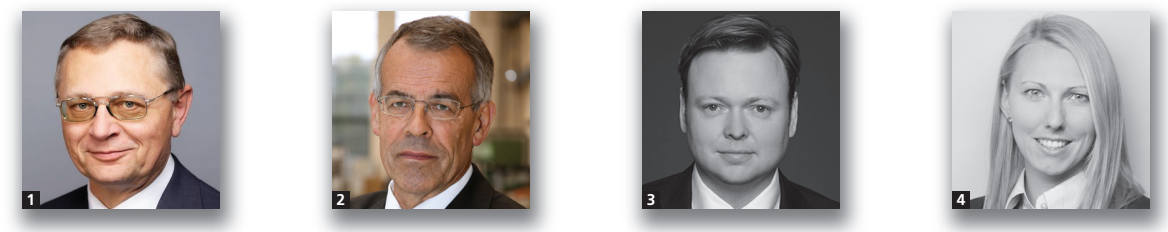

The federal report on public-private partnerships (PPPs) in the building sector, published in 2003, can be considered as the cornerstone for the realisation of PPP projects in Germany. Today, 10 years later, this paper draws a balance and takes a look back on 10 years of daily dealings with PPP projects. The aim of this paper is to give an overview of the German PPP market and the experiences that have occurred in the context of procurement, financing and the realisation of PPP projects themselves. First of all a definition is given of PPP in Germany and a short overview is presented of the history of PPP and the different types of PPP contracts. A short survey analyses PPP projects in the building construction and road sectors. Then, the experiences in preparation and realisation are summarised and evaluated. Finally, the paper presents a closer look at the actual and future development of PPP in Germany with consideration of critical aspects and possible solutions.

\section{Definition of PPP in Germany}

A public-private partnership (PPP) project as a holistic model combines planning, construction, financing, operating as well as maintaining public infrastructure by private contractors. The aim of this life-cycle approach is to analyse and to optimise the costs over the entire project lifetime and allocate the risk by risk-management-competence (Bundesministerium für Verkehr, Bau und Stadtentwicklung, 2003).

PPP is connected with the expectation that, in contrast to conventional procurement by the public authority, advantages can be achieved by

a total cost optimisation by implementation of the life-cycle approach

- optimal risk allocation between the private and the public sector

know-how transfer from the experiences of private partners and

implementation of incentive structures for further optimisation (e.g. bonus-malus schemes).

PPP is one of several procurement options. Decisive for the selection of the procurement model is economic feasibility, which must be determined by economic analysis and compared to common and alternative procurement options.

PPP projects as long-term contractual collaborations between the public and private sector are characterised in particular by the following principles (Jacob and Kochendörfer, 2002).

- Risk allocation: the optimal risk allocation between the public and the private partner is one of the essential elements of PPP models. The so-called risk-sharing principle is applied, which states that the risk should be transferred to the partner who is best able to manage it.

Life-cycle approach: best possible coordination of design, construction, maintenance and supporting services over the life of the contract.

Output specifications: the specification of a PPP tender is functional and output oriented (function, purpose, standards, qualities). The bidders decide in what way these requirements are met.

- Performance-based payment mechanism: the private partner receives a performance quality, availability or userelated compensation. To create an incentive for optimisation, performance-based mechanisms, for example bonus/ malus schemes, are used. 


\section{History of the German PPP market}

In Germany the first wave of PPP projects started shortly after the beginning of the new century. One of the first PPP projects was a tunnel called Warnowtunnel near the city of Rostock in the northern part of Germany. Not everything went well in the project, so a lot of lessons were learned in the end, but let us start where all this began, just a few years before. A delegation from the state of North Rhine-Westphalia travelled to England, following an invitation to get to know something called the private finance initiative. After coming back a few days later the politicians were amazed at the new model that combined all phases of the life cycle with the aim to be more efficient than the conventional procurement.

This was the start of an important phase in Germany, and there are now approximately 200 projects (see Figure 3, later). The state of North Rhine-Westphalia is still the leading state in Germany when it comes to the number of PPP projects.

\section{Different contract models in Germany}

In the context of PPP different contractual models are used in Germany. In particular, these models differ in terms of their ownership structure, the compensation scheme and the risk allocation. The most common models are outlined below (Bundeministerium für Verkehr, Bau und Stadtentwicklung, 2003).

(a) Erwerbermodell (build-operate-transfer, BOT-model): In the BOT-model the private contractor is responsible for planning, construction, financing and operation of a property that is used by the public authority. The term of such contracts is usually 20-30 years. At the end of the contract, the ownership of land and buildings is transferred to the public authority. The fee comprises a periodic payment to the contractor that is to be fixed in the contract and combines both the remuneration for designing, constructing, operating (facility management) and financing as well as the acquisition of the property, including land and, furthermore, includes possible surcharges for commercial profit and the transfer of risk.

(b) Inhabermodell (build-transfer-operate, BTO-model): The BTO-model is comparable to the BOT-model (see above). However, in contrast the property is owned by the public authority from the start. The property is used by the private contractor either to construct new real estate or to rehabilitate already existing buildings. The BTOmodel is used in about $70-80 \%$ of all PPP projects in Germany.

(c) Leasingmodell (build-operate-own, BOO-model): The private contractor is responsible for the planning, construction, financing and operation of a property. However, compared to the BOT-model, there is no obligation to transfer the ownership of the building at the end of the contract period to the public authority. Instead the public authority has the option either to return the property or to purchase it for a pre-calculated residual value. In addition to the option to purchase or lease the property, extension and exploitation agreements can be considered. As a user fee the public authority pays regular and contractual fixed instalments ('lease') to the contractor. The price for which the public authority can acquire the property at the end of the contract period, has to be fixed at the time the contract is concluded.

(d) Mietmodell (build-operate-own, BOO-model): The rental model is similar to the leasing model, but without an option to buy the object for a predefined price. The asset can be purchased for the market value, which is determined at the expiration time of the contract. The public authority shall pay to the contractor regular instalments as agreed in the contract; the components of these rates are the fees for the use (rent) and operation (facility management).

(e) Contractingmodell: The contracting model obligates the private contractor both in constructing as well as optimising operational measures of certain technical equipment in a building owned by the public authority. The duration of such contracts ranges between 5 and 15 years. The fee is agreed in the contract and usually covers planning, implementing, operating and financing costs of the private contractor.

(f) Konzessionsmodell (concession model): According to the concession model, the private contractor agrees to operate the business on its own economic risk. Therefore, the public authority grants the private contractor a concession that allows the refinancing of its costs directly by the users of the facility. That means the private contractor is directly in a contractual relationship with the users. The subject of such concessions can be both a construction and a service. Regarding the transfer of ownership, different arrangements are possible; for example, automatic transfer of ownership to the public authority without a final payment of compensation. The public authority may, if appropriate, support the project by an initial payment or grant subsidies to ensure the success of the project.

(g) Gesellschaftsmodell (shareholder model): In the shareholder model the public authority engages a specialpurpose vehicle (SPV) as a shareholder to be part of the company that is in charge of the project during the contract life. The shareholder arrangement may be combined with other PPP contract models as described above.

\section{Survey of the German PPP market}

Since 2003, 200 projects with a total investment of $€ 8 \cdot 1$ billion have been realised in building and road construction. The 
achieved savings of $13 \cdot 7 \%$ correspond to more than $€ 1$ billion (Öffentlich-Private Partnerschaften in Deutschland, 2013). While construction projects are focusing on the areas of health, education and government, in the road sector the Amodels are in high demand.

In 2013, the development of the German market for PPP was very weak (see Figure 1). Only 12 PPP construction projects with an investment volume of approximately $€ 305$ million had been awarded. Only one municipal road project with a volume of approximately $€ 10$ million had been awarded.

The number of projects decreased in the fourth consecutive year. One reason for this development is the future investment programme, the so-called stimulus package (in German Konjunkturpaket II, KP II) from the federal government. Many projects that should have been implemented by means of PPP have been either postponed or implemented with funds from this programme in a conventional procurement. The involvement of the KP II funds in PPP projects has succeeded in only a few cases.

\subsection{PPP in building construction}

In the building construction sector 200 projects have been realised to date. As Figure 2 shows, the major part of projects has been awarded in the education sector. The average investment volume of these projects does not exceed $€ 27 \cdot 3$ million, whereas in the health sector projects with an average investment of $€ 88.7$ million have been accomplished.

Currently there are 27 construction projects with an expected investment volume of more than $€ 1.25$ billion in tender Another 51 projects with an expected investment volume of $€ 1.5$ billion are in preparation.

\subsection{PPP in road construction}

In the transportation sector, 13 projects have been awarded a total investment of $€ 2.35$ billion since 2007. In the area of federal highways (Autobahnen) more projects will follow: the

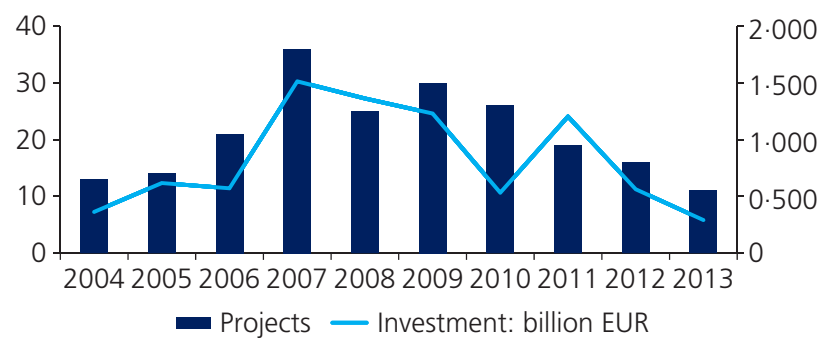

Figure 1. PPP in Germany until December 2013 (source: authors' own representation based on www.ppp-plattform.de) tender for the A-model on the A7 Hamburg-Bordesholm was published in 2012. It is expected that the Federal Ministry of Transport, Building and Urban Development will initiate three more PPP projects in road construction to the market in 2014 (Müller, 2013).

\subsection{Regional distribution of PPP}

The PPP model has not spread evenly all over Germany. Figure 3 gives an overview of the distribution of PPP projects among the federal states. Whereas in North Rhine-Westphalia 59 projects have been realised so far, in Berlin - the capital city of Germany and a state - only two projects can be counted, and one of these is the British Embassy, which, although being a PPP project, is not a German one. The construction of the British Embassy with an investment volume of approximately $€ 32.72$ million was one of the first PPP projects in Berlin. The concession contract was signed in June 1998 for an initial period of 30 years.

Looking at the map the question arises as to why the spread is so uneven all over Germany. This probably has to do with two things. A lot of political power in Germany lies within the hands of the federal states, the cities within or even the municipality. This means that every municipality or city has its own freedom of choice regarding whether to use a PPP model or not. The other effect that could explain the uneven spread of PPP projects in Germany is which political party is in power in the particular states.

\section{Experiences in preparation and procurement processes}

The process of project preparation and realisation comprises four phases, which are shown in Figure 4.

Article 7, paragraph 2, sentence 1 of the Federal Budget Code (Bundeshaushaltsordnung (BHO, 2013)) regulates proper feasibility studies to be carried out for all financial activities, such as investments in real estate.

The economic feasibility study is used as a tool to determine which procurement model can be seen as the most economical. In each phase of the economic feasibility study, decisions can be made on the further development of the project. The economic feasibility study serves as a management and controlling instrument. The findings of the economic analysis will be incorporated into the process of the project development and project management.

An economic feasibility study is a multistep process, which takes all costs and revenues into account to predict the most economical alternative. The process is characterised by a continuous increase in project-related information. The purpose is a reliable quantitative estimation of the possible lifecycle costs of each procurement option. 


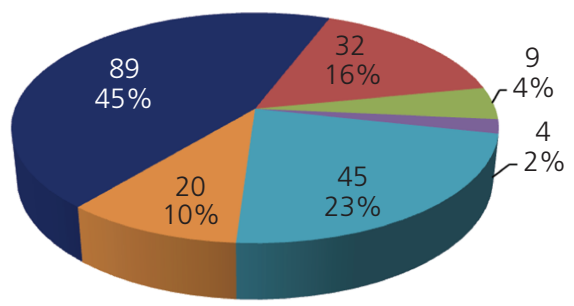

(a)

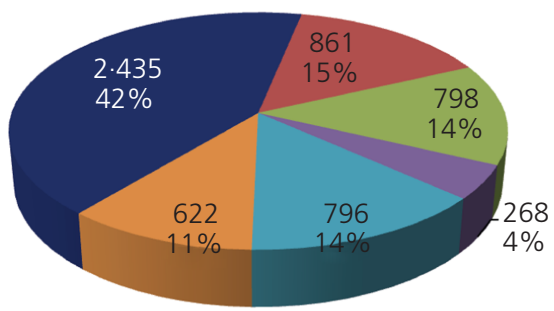

(b)

$\begin{array}{lll}\text { - Education } & \text { Administration } & \text { Health } \\ \text { - Justice } & \text { Sport / culture } & \text { Others }\end{array}$

Figure 2. Distribution of PPP projects in building construction until January 2014: (a) distribution by number or projects;

(b) distribution by investment volume (million EUR) (source:

authors' own representation based on www.ppp-plattform.de)

As shown in Figure 4, the process of project preparation and realisation includes four phases, each containing specific instruments. The first three phases end with a decision whether to continue the PPP process or to engage a conventional procurement.
Phase 1 includes the identification of needs as well as the PPP fitness test. At the end of that phase, a preliminary decision on whether or not to follow the realisation alternative for PPP is taken. Although a decision in favour of a PPP procurement is not yet exclusive, a decision against PPP at this point of the

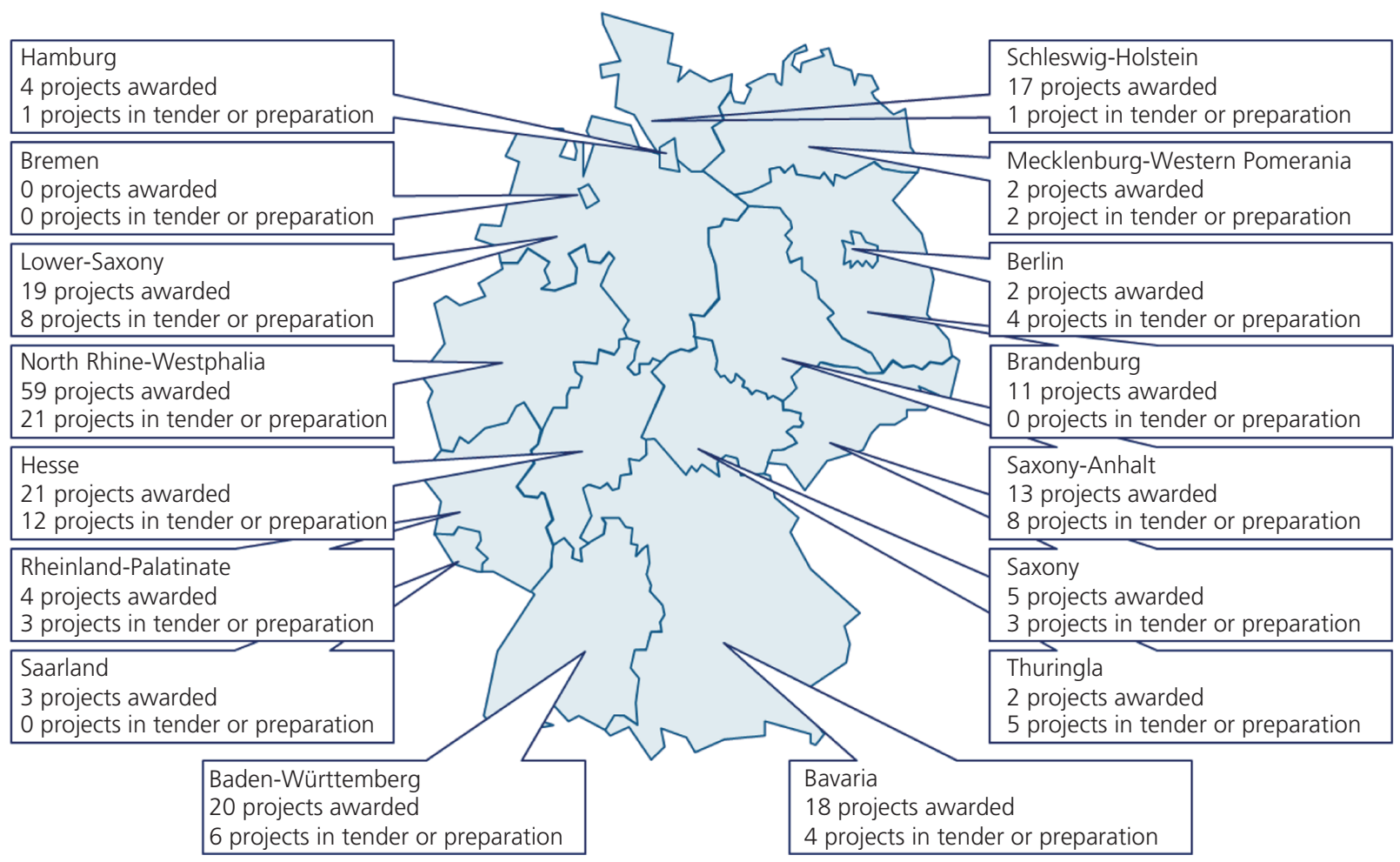

Figure 3. Regional distribution of PPP projects in Germany until January 2014 (source: authors' own representation based on www.ppp-plattform.de) 


\begin{tabular}{|c|c|c|c|}
\hline Phase 1 & Phase 2 & Phase 3 & Phase 4 \\
\hline $\begin{array}{l}\text { - Identification of } \\
\text { needs } \\
\text { - PPP fitness test }\end{array}$ & $\begin{array}{l}\text { - Public sector } \\
\text { comparator } \\
\text { - Preparation of the } \\
\text { tendering procedure }\end{array}$ & $\begin{array}{l}\text { - Tendering procedure } \\
\text { - Conclusion of contract } \\
\text { - Financial close } \\
\text { - Final feasibility study }\end{array}$ & $\begin{array}{l}\text { - Project realisation } \\
\text { - Controlling }\end{array}$ \\
\hline \multicolumn{3}{|c|}{ Economic feasibility study } & Evaluation \\
\hline
\end{tabular}

Figure 4. Phases of project preparation and realisation (source: authors' own representation based on Finanzministerkonferenz der Länder (2006))

PPP process leads automatically to the implementation of a conventional procurement.

The aim of phase 2 is to compare both procurement methods by comparing the public sector comparator (PSC) with the estimated offer of a private bidder. At the end of this phase, a decision must be made regarding whether a tender process should be engaged - conventionally or as a PPP project.

At the end of phase 3 the final economic feasibility study is made in which the tenders and the conventional comparison value (PSC) are compared. If this phase ends with a proved profitability of the PPP project, the successful tenderer can be awarded and the contract can be signed.

Finally, phase 4 consists of the continuous project controlling during the contract period. In this phase it is important to take the final settlements of the contract into account, which were adopted in the economic analysis (Finanzministerkonferenz der Länder, 2006).

\section{Best practice in financing}

In most PPP projects realised in Germany financing is part of the performance package that is transferred to the private partner. The investment of the construction is therefore usually refinanced by bank loans at the level of the private contractor.

The interim financing of the private contractor during the construction phase is usually replaced by a long-term loan when the project has reached its approval by the public authority. The costs of interim financing are added to the construction costs and are included in the rates paid by the public authority.

The interim financing is based on either a variable or fixed interest rate. Which rate is used depends on the current yield of the money market and the assessment of their development in the construction phase. To ensure comparability between financial conditions in the bid comparisons, appropriate reference rates are set by the public authority. Usually Euribor rates (e.g. 1-month Euribor) are used as a reference for variable interest rates, and other reference rates (e.g. Isdafix) are used for fixed interest rates.

For the private provision of capital for PPP projects in Germany two different financing models are applied, namely the model with the non-recourse forfaiting of instalments (the so-called Forfaitierung mit Einredeverzicht) and the project financing model. The majority of German PPP projects are implemented with the non-recourse forfaiting model.

\subsection{Non-recourse forfaiting of instalments model}

Non-recourse forfaiting of instalments is a common form of financing that is used in a variety of small to medium-sized PPP projects in Germany (see Figure 5). In the conventional procurement of public projects, the funds required are usually recorded on the public budget as a so-called 'Kommunalkredit' (municipal loan). As public authorities face a considerable high credit rating in Germany, significantly more favourable interest rates can be achieved, compared to commercial financing by the private sector. These municipal loan financing conditions

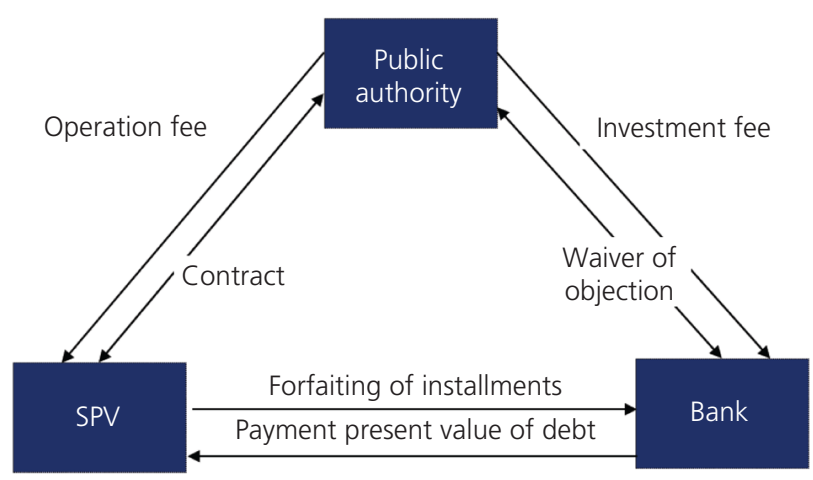

Figure 5. Non-recourse forfaiting of instalments (source: authors' own representation based on Eppinger et al. (2008)) 


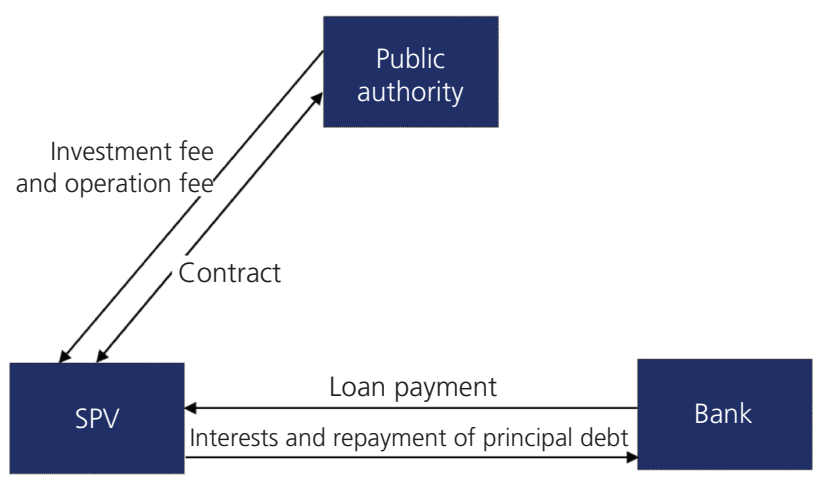

Figure 6. Project financing (Source: authors' own representation based on Eppinger et al. (2008))

provide the benchmark for alternative financing options in PPP projects.

To use the advantages of financing as the public sector within PPP projects, the so-called 'objection-free forfaiting' was established in Germany as a financial model for PPP projects. In this model, the interim financing is done by the private contractor and his financing bank. After completion and acceptance of the entire construction, the funding will be transferred partially to the public authority. Through the acceptance of the waiver the lending bank reduces the risk of non-payment or late payment. The financing bank may therefore base their decision solely on the creditworthiness of the public sector as the principal debtor. In this way municipal loan financing conditions can be achieved within PPP projects.

The public authority on the other hand shall not lose its rights against the private partner by accepting the non-recourse forfaiting of instalments. The waiver of the objection is only declared after the completion of the entire construction process and acceptance by the responsible authorities. Also the non-recourse forfaiting is limited to the money spent on the investment in the first place. The money paid during the contract lifetime for the operation and refurbishment is paid in regular shares and can be reduced or interrupted if necessary.

The recognition of the duty provided with a waiver of objection to the assignment of future receivables in the public deficit balance after the Maastricht debt criteria (Eurostat) is dependent on the individual case (Weber et al., 2004).

Both financial models require the implementation of a SPV. It is usually established as a limited company $(\mathrm{GmbH})$ or limited partnership ( $\mathrm{GmbH} \& \mathrm{Co}$. KG). However, it is not only to be considered as a financing vehicle as it also takes over management and ownership functions for the project.

\subsection{Project financing}

In the context of project financing, the funds will be applied $80 \%$ to $90 \%$ by lenders. Regarding the cost of financing the public sector is in a conflict of interest at this point. On the one hand it aims to minimise the costs of financing by reducing the equity ratio. On the other hand, the public sector needs to merge its own and private contractors' interests in order to achieve security and economic stability in the project. A high equity participation of the sponsors is viewed in this context as a credible assurance to comply with contractual agreements and to refrain from opportunistic behaviour.

As the project financing is based solely on the project plan itself (cash flow related), the PPP project contract between the project company and the public authority is of central importance in the risk assessment. There is no direct contract relationship between bank and public authority (Figure 6). The detailed analysis and calculation of the planned project (legal, technical, fiscal and financial due diligence) by the banks and their active role and influence on the financial planning and contract design is typical of project financing (Napp, 2011).

\subsection{Basel III and PPP financing}

The implementation of the reform package 'Bale III' will have an impact on the financing of PPP projects. The qualitative requirements in terms of shareholders' equity are tightened. In addition, a new leverage ratio and liquidity requirements are introduced. Especially for heavily indebted local governments, the situation will worsen as the credit rating of the public sector will be evaluated more precisely and strictly in the future.

Against this background, it is expected that the participation of institutional investors in PPP projects, such as insurance providers, will continue to increase. These can participate by way of debt and equity funds or through project bonds (Jacob and Stuhr, 2013; Jacob et al., 2013).

\section{Best practice in construction and exploitation}

Some examples of good PPP practice from the construction and infrastructure sector are presented below. It is shown how the PPP model can be used to realise projects with a particular complexity or special requirements in quality.

\subsection{PPP and energy efficiency: implementation of private know-how to ensure high energy standards}

The SeeCampus Niederlausitz is a building centre in Schwarzheide, Brandenburg. The building unites various educational institutions. It is the first PPP school building in a zero-energy housing standard. During the construction phase it was awarded with the 'Innovation Award for Public Private Partnerships' in 2010. Additionally, in June 2012, the building was awarded the silver 
certification of the German Society for Sustainable Building (DGNB). In September 2012, the German Energy Agency (dena) certified the zero-energy standard and also named it as a good example of energy efficiency and energy savings with the 'good practice label'. The three-storey education centre was opened in February 2011. It is a site for a school, a senior high school and a library. The area integrates a sports hall, a canteen and cafeteria and extensive outdoor facilities. The three-storey building is situated on a mining rehabilitated land area on the north shore of a pond.

\subsection{Federal Ministry of Education and Research in Berlin}

The new building of the Federal Ministry of Education and Research (BMBF) in Berlin is one of the first civil construction PPP projects in the capital city of Berlin. The ministry in the vicinity of Berlin's main train station combines the high standards of quality of design and urban integration with sustainability and energy efficiency. The PPP contract transfers planning, construction, operation and maintenance of the building and the technical equipment to a private partner. In the final economic study the comparison of the present values of the conventional implementation (PSC) with the offer of the private partner showed a net present value of $9 \cdot 5 \%$ for the PPP deal. Savings of approximately $€ 28$ million over the contract period can thus be achieved by implementing a PPP project. The cornerstone was laid in June 2012, and in October 2012 the project was awarded the PPP innovation award. On completion, the object is to be certified gold status under the sustainable building rating system (DGNB).

\subsection{PPP Highways: change of payment structure}

The Federal Ministry of Transport, Building and Urban Development selected four pilot projects to gain experience with the long-term, contractually agreed cooperation between the public and private sector. The A5 between Karlsruhe and Basel is a major route of European importance, with a very high traffic volume of approximately 70000 vehicles per day and one of the selected pilot projects.

One part of this so-called A-model is the six-lane expansion of the highway (between 2009 and 2015). Another part is the 30year operation and maintenance phase of the motorway over $60 \mathrm{~km}$ (from 2009 to 2039) by the concessionaire. The federal government remains owner of the highway. To refinance its costs, the private partner receives revenues from the German motorway truck toll for this section of road. The construction volume amounts to $€ 350$ million (www.vifg.de).

\subsection{Evaluation of the first PPP project in exploitation: user satisfaction is high}

In a first evaluation in 2009 six pilot projects of the task force of North Rhine-Westphalia were investigated. The municipalities that took part in the survey were very satisfied with regard to the procedures performed and the results achieved by their PPP projects. The PPP procurement model has proved itself in the PPP pilot projects from today's perspective. The projects were completed to a high standard and within the time that was appointed in the contract. As a particular advantage of PPP the good quality of service and the rapid response and resolution times of the operator were named by the participants of the survey (Jacob and Neunzehn, 2010).

According to a survey by the Institute Allensbach in 2012, 90\% of the public authorities evaluate the cooperation with a private partner as advantageous. Even among users, 78\% of principals and $68 \%$ of parent representatives rate their PPP project positive.

The study also shows that PPP projects from a user's perspective are not connected to a loss of service quality. In contrast, $95 \%$ of the clients are generally satisfied with the quality of cooperation, $87 \%$ praised the quick response of the private partner to complaints and $84 \%$ praised how well defects in general were eliminated. Three quarters of clients were also sure that without PPP the construction and rehabilitation measures would not have been, or would only partially have been, implemented, at least until much later.

Another indication of the positive value of a PPP is a survey of the Offenbach district in which the users of 100 PPP schools were interviewed. Nearly $80 \%$ of principals felt satisfied or very satisfied with its private partners. The accessibility to the company was rated by more than $90 \%$ of respondents as at least good, the facility management services as at least $88 \%$ good. Complaints had been given only in individual cases.

An actual evaluation of 56 projects proves the high standard of PPP projects in terms of quality, respect of delivery and cost control (Hauptverband der Deutschen Bauindustrie, 2014).

\subsection{SME participation remains high}

The German PPP market is characterised particularly by its small-scale investment in European comparison: 147 of the total 200 projects have an investment amount of up to $€ 30$ million; 24 projects are in the range $€ 31-70$ million. Only 18 projects have a total investment of more than $€ 70$ million. The small volume of the projects may be due to the fact that the large number of projects is carried out at the municipal level. Owing to the tighter municipal budgetary scope, major projects are implemented only sporadically.

This characteristic feature of the German PPP market is also found in PPP construction projects of 2012. The investment of 12 of the 14 construction projects accounted for $€ 6-30$ million of the investment value. Only two projects are above that value: 
a school package consisting of 15 selected schools in Hamburg, with a value of $€ 315$ million and another school in the district Miesbach (Bavaria) with more than $€ 55$ million investment.

From the perspective of small and medium enterprises (SMEs), the smaller project size should be seen as an opportunity, as this makes their participation in PPP projects also possible on the first contractor level. This is demonstrated by PPP statistics since 2002: 93 of 200 PPP construction projects were awarded on first-contractor level directly to SMEs. This corresponds to a share of $46 \%$. In 2012, $60 \%$ of project agreements were signed by SMEs as the first contractor. At the same time studies show that between $60 \%$ and $70 \%$ of the project contract volume will be forwarded to regional integrated SMEs and craft enterprises (Müller, 2013).

\section{Latest developments and outlook}

The experiences of 10 years of PPP have been analysed above. Now the authors will take a closer look at the current situation and the expected developments.

\subsection{Critical evaluation of the PPP model}

Recently, PPP has been exposed to criticism. Doubts about the economic viability have been announced and the lack of transparency has been criticised. Another critical point was the lack of involvement of SME enterprises.

One of the projects that has been subject to a critical examination on PPP is the so-called 'Elbphilharmonie' in Hamburg. The project is characterised by a massive cost overrun, which is caused by the award of separate contracts for planning and construction. This approach contradicts the classic PPP model in which planning, construction, financing and exploitation are awarded to one single contractor (Fischer et al., 2013).

\subsection{PPP transparency initiative}

PPP projects have been criticised owing to lack of transparency. Transparency is not only a prerequisite for a proper and responsible investment decision, it is necessary to create the acceptance for the investment decisions made.

Against this background, the construction companies launched a 'PPP transparency initiative' in 2011. In this initiative companies are committed to the disclosure of the PPP contracts. The implementation has to be realised in partnership with the contracting authority. Although the public authorities were initially reluctant, the response to the initiative on the public side is mostly positive now, especially in the municipal sector.

Despite the publication of the contracts, the intellectual property involved on both sides is protected, and the confidentiality of special technical knowledge and know-how-based advantages has to be guaranteed. This is the only way to maintain the price competition and competence as a fundamental part of the PPP procurement model.

In addition to the publication of the contracts, the creation of a supplementary project report is recommended. This summarises key financial data and indicators, answers frequently asked questions and shows the allocation of risks between the parties.

One fact can be stated with certainty: owing to the transparent documentation of the project cost certainty and adherence to schedules can be proved. (The disclosed contracts were published on www.ppp-plattform.de.)

\subsection{Outlook 2014: market upturn is expected}

Compared to 2012 and 2013, a slight upward trend can be observed. Since the middle of 2013 some projects at the municipal level have already been awarded. Many projects are in the pipeline.

Contrary to the general trend of critical opinion, there are signs that the good experience with PPP projects has motivated some public authorities to start second or third projects. Here in particular the municipalities play an important role. Of the 11 local authorities that realised PPP projects in 2012, five had already implemented project experiences with PPP in public building and at least one more project at an earlier date. Therefore it seems likely that the experience of working together with a private partner leads to another application of the PPP model and at the same time demonstrates the potential benefits of PPP.

After the elections in Germany in September 2013 both big political parties on the federal level stated clearly in their political agenda that, for the next few years, they would continue to use the PPP model to receive better value for money (CDU, CSU und SPD, 2013). The methodology of PPP feasibility studies is subject to evaluation and standardisation.

The expected PPP investment volume for 2014 amounts to approximately $€ 1 \cdot 3$ billion in the building construction and the road sectors.

\section{REFERENCES}

BHO (Bundeshaushaltsordnung) (2013) Anforderungen an Wirtschaftlichkeitsuntersuchungen finanzwirksamer Maßnahmen nach § 7 Bundeshaushaltsordnung. Band 18. Der Präsident des Bundesrechnungshofes als Bundesbeauftragter für Wirtschaftlichkeit in der Verwaltung, Bonn, Germany (in German).

Bundesministerium für Verkehr, Bau und Stadtentwicklung (2003) PPP im öffentlichen Hochbau, Vol. 1, part I.

Bundesministerium für Verkehr und digitale Infrastruktur, Berlin, Germany. See http://www.bmvi.de/SharedDocs/DE/ 
Anlage/BauenUndWohnen/gutachten-ppp-imoeffentlichen-hochbau-band-1.pdf?_blob=publicationFile (accessed 08/08/2014) (in German).

CDU, CSU and SPD (2013) Deutschlands Zukunft gestalten Koalitionsvertrag der Bundesregierung. See http://www. bundesregierung.de/Content/DE/StatischeSeiten/Breg/ koalitionsvertrag-inhaltsverzeichnis.html (accessed 25/06/ 2014) (in German).

Eppinger F, Käsewieter H-W and Miksch J (2008) Die Bedeutung der Finanzierung innerhalb eines PPP-Projektes. In Public Private Partnership (Meyer-Hofman B, Riemenschneider F and Weihrauch $\mathrm{O}$ (eds))., 2nd edn. Carl Heymanns, Cologne, Germany, pp. 344-394 (in German).

Fischer K, Haerder M, Krumrey H et al. (2013) Besser regieren, weniger Zahlen. Wirtschaftswoche 23: 20-27 (in German). Hauptverband der Deutschen Bauindustrie (2014) ÖPPPraxistest bestanden! See http://www.oepp-plattform.de/ media/attachments/OEPP-Praxistest_Kurzumfrage_final. pdf (accessed 25/06/2014) (in German).

Jacob D and Kochendörfer B (2002) Effizienzgewinne bei privatwirtschaftlicher Realisierung von Infrastrukturvorhaben; Eine Forschungsarbeit über Effizienzgewinne durch Public Private Partnership im öffentlichen Hochbau und Straßenbau. Bundesanzeiger Verlag, Cologne, Germany (in German).

Jacob D and Neunzehn D (2010) Zusammenfassung der Ergebnisse zum Forschungs- und Entwicklungsvertag.
Finanzministerium des Landes Nordhein-Westfalen, Düsseldorf, Germany. See http://www.ppp.nrw.de/ oeffentlichkeitsarbeit/veroeffentlichungen/ evaluierung_synopse_ppp.pdf (accessed 25/06/2014) (in German).

Jacob D and Stuhr C (2013) Finanzierung und Bilanzierung in der Bauwirtschaft, 2nd edn. Springer Vieweg, Wiesbaden, Germany (in German).

Jacob D, Hilbig C and Reuter T (2013) Kommunalkredit - Die Zukunft der PPP-Finanzierung unter Basel III. Immobilien \& Finanzierung 18: 22 (in German).

Müller T-O (2013) Der ÖPP-Markt 2012: Talsohle erreicht? In PPP-Jahrbuch 2013 (Kop D (ed.)). Convent, Frankfurt, Germany, pp. 37-42 (in German).

Napp H-G (2011) Die Finanzierung von öffentlich-privaten Partnerschaften (PPP) - Grundlagen und aktuelle Entwicklungen. Kommunalwirtschaft, Sparkassen im kommunalen Raum (Special issue): 53-59 (in German).

Öffentlich-Private Partnerschaften in Deutschland (2013) http:// www.partnerschaften-deutschland.de/fileadmin/Daten/ OEPP-Markt/OEPP-Marktzahlen/131106_OEPP_ Deutschland_AG_Halbjahresbericht.pdf (in German). Weber M, Moss O and Schwichow H (2004)

Finanzierungsleitfaden. In Schriftenreihe Public Private Partnership-Initiative NRW. Public Private Partnership im Hochbau, Düsseldorf, Germany, 2004 (in German).

\section{WHAT DO YOU THINK?}

To discuss this paper, please email up to 500 words to the editor at journals@ice.org.uk. Your contribution will be forwarded to the author(s) for a reply and, if considered appropriate by the editorial panel, will be published as discussion in a future issue of the journal.

Proceedings journals rely entirely on contributions sent in by civil engineering professionals, academics and students. Papers should be 2000-5000 words long (briefing papers should be 1000-2000 words long), with adequate illustrations and references. You can submit your paper online via www.icevirtuallibrary.com/content/journals, where you will also find detailed author guidelines. 